\title{
INDAHNYA KEBERSAMAAN \\ [Sebuah Ikhtiar dalam Membangun Kampus Bertaqwa Untuk Membawa Berkah (BERUBAH) dalam Perspektif Hadis]
}

\author{
La Ode Ismail Ahmad \\ Pascasarjana UIN Alauddin Makassar \\ Laode.ismail@uin-alauddin.ac.id
}

\begin{abstract}
Abstrak: Islam adalah agama kebersamaan. Ajakan agama untuk hidup bersama dilandasi oleh posisi, kedudukan dan kapasitas manusia sebagai makhluk sosial. Salah satu upaya yang efektif dalam memperkukuh kebersamaan adalah kesadaran untuk mengembangkan dialog secara intensif di kalangan anggota masyarakat, baik antara satu individu dan individu lain, maupun antara satu kelompok dan kelompok lain dalam suatu masyarakat. Kebersamaan dalam Islam disebut dengan al-jama'ah. Makna al-jama'ah dalam hadis dari 171 kali penyebutannya, dapat dikategorisasikan -untuk sementara sebagai kajian awal-dalam empat hal, yakni kebersamaan dalam ibadah, kebersamaan merupakan sumber rahmat, kebersamaan merupakan sumber berkah dan kebersamaan melahirkan 'tangan' [kekuasaan dan pertolongan] Allah.

Kebersamaan merupakan sumber rahmat dari Allah swt., karena rahmat-Nya hanya terdapat pada mereka yang menyebarkan rahmat di muka bumi. Mereka dapat membangun hidup dengan kebersamaan jika tidak ada kebencian dan kecemburuan dalam dada mereka, yang ada hanyalah kasih sayang di antara mereka. Kebersamaan akan melahirkan kebaikan-kebaikan sebagai implikasi dari saling menghormati, saling membantu, saling merasakan dan saling menghargai di antara anggota masyarakat. Prinsip dan karakter seperti ini harus dimiliki oleh setiap orang agar tercipta sebuah kerukunan dalam berinteraksi secara horizontal.

Kebersamaan dapat dibangun jika masing-masing individu memiliki sikap untuk saling memberi pertolongan. Pertolongan kepada sesama manusia akan melahirkan pertolongan dari Allah swt. Dalam sebuah hadis yang diriwayatkan oleh Bukhari dan Muslim dari sahabat Abu Hurairah, Nabi bersabda, 'Allah akan selalu memberi pertolongan kepada seseorang selama ia memberi pertolongan kepada saudaranya [sesamanya]. Ungkapan Nabi di atas menunjukkan bahwa pertolongan Allah akan datang melalui kerjasama antara manusia. Sebagai makhluk sosial, seseorang harus sadar bahwa ia tergantung kepada pihak lain, di mana kebutuhannya tidak dapat terpenuhi melalui usahanya, usaha kelompoknya bahkan usaha bangsanya sendiri. Hidup hanya mungkin dan nyaman apabila dibagi dengan orang lain, sehingga masing-masing berperan serta dalam menyediakan kebutuhan bersama.
\end{abstract}

Keywords: Hadis, Kebersamaan (al-Jama'ah) 


\section{PENDAHULUAN}

Slogan mengenai pentingnya kebersamaan telah menjadi ungkapan dalam kehidupan sehari-hari yang membuat mulut "berbusa-busa" mengucapkannya. Dalam dunia politik, slogan-slogan tersebut kadangkala dibuat hanya sekedar sebagai pencitraan belaka untuk menarik simpatik publik. Dalam realitasnya, orang yang telah mencapai segala keinginannya kemudian "melupakan" urgensi dan signifikansi kebersamaan dalam ruang yang lebih luas. Mereka hanya membangun kebersamaan dalam kelompoknya, tanpa mengajak kelompok yang lain.

Dalam perspektif agama, Islam yang berlandaskan pada Alquran dan hadis, sangat menekankan kebersamaan. Bahkan kita bisa mengatakan bahwa Islam adalah agama kebersamaan. Ajakan agama untuk hidup bersama dilandasi oleh posisi, kedudukan dan kapasitas manusia sebagai makhluk sosial. ${ }^{1}$ Artinya, manusia adalah makhluk yang tidak bisa hidup sendirian, tanpa bergantung kepada yang lainnya. Kehadiran manusia di bumi sejak awal kehidupannya telah melibatkan orang lain.

Selain sebagai makhluk sosial, manusia juga berkedudukan sebagai makhluk individu. Dualitas kedudukan manusia ini menyebabkan ia selalu dalam keadaan memilih antara pemihakan terhadap kepentingan individu dan pemihakan kepada kepentingan bersama secara kolektif. Pertarungan antara dua kutub kecenderungan yang berbeda inilah yang melahirkan paham individualisme (egoisme) di satu sisi dan kolektivisme (sosialisme) di sisi lain. Kondisi ini merupakan konsekuensi logis dari naluri bawaan sejak lahir yang oleh Sigmund Freud (1856-1939) disebut sebagai id. Dorongan ini cenderung membuat seseorang untuk memenuhi kebutuhannya tanpa memperdulikan kepentingan orang lain, yang secara diametral bertentangan dengan norma-norma sosial yang membatasi dan menghalangi keinginan id. Untung saja ketegangan psikologis yang terjadi akibat pertentangan kecenderungan antara id dan super ego ditengahi oleh ego yang menghasilkan kompromi sebagai jalan tengah mengatasi konflik psikis tersebut. ${ }^{2}$

Dengan kata lain, manusia adalah maujud bebas. Tuhan telah memberikan kebebasan yang demikian luas kepada manusia sehingga ia mampu menentukan tabiat dan wataknya sendiri. Tidak hanya dirinya, dunia ini pun manusia yang menentukan masa depannya. Terserah dia bagaimana dan ke mana ia akan

\footnotetext{
${ }^{1}$ Menurut M. Quraish Shihab, argumentasi Alquran dari tesis manusia sebagai makhluk sosial adalah ayat kedua dari firman-Nya dalam wahyu pertama 'Khalaq alInsāna min 'Alaq'. Dari sisi etimologi, kata 'alaq berarti seseuatu yang tergantung, karena salah satu tahap kejadian manusia ketika berada dalam kandungan adalah ketergant ungan hasil pertemuan sperma dan ovum yang membelah dan membelah sambil berjalan menuju dinding rahim lalu bergantung at au berdempet dengannya, yang disebut zygote oleh pakar embriologi. Kata 'alaq dapat juga berarti ketergantungan manusia kepada pihak lain karena tidak dapat hidup sendiri. Lihat M. Quraish Shihab, Dia Dimana-mana: Tangan Tuhan Dibalik Setiap Fenomena (Cet. IV; Jakarta: Lentera Hati, 2006), h. 153.

${ }^{2}$ Lihat Norman Said, 'Memperkukuh Relasi Sosial Menuju Indonesia Baru', dalam Titik-Temu, Vol. 2, No. 1, Juli-Desember 2009, h. 50.
} 


\section{INDAHNYA KEBERSAMAAN \\ [Sebuah Ikhtiar dalam Membangun Kampus Bertaqwa Untuk Membawa Berkah (BERUBAH) dalam Perspektif Hadis]}

membawa dunia ini. Demikian pula lembaga STAIN ini; apakah ia berubah menjadi IAIN; apakah ia memiliki program pascasarjana, sangat tergantung kita semua yang menjadi bagian dari kampus ini. Pertanyaannya, mau dibawa kemana STAIN ini; wajah STAIN sangat tergantung wajah-wajah kita. Namun dalam kebebasannya itu, tampaknya manusia rentan godaan yang teraktualkan dalam drama kosmis kedua nenek moyang manusia, Adam dan Hawa. Keterpurukan itu tidak lain karena dalam diri manusia sudah ada potensi-potensi ruhani yang bisa membawanya kepada keburukan; dan ada pula potensi-potensi ruhani yang bisa membawanya kepada kebaikan. ${ }^{3}$ Dalam firman Allah disebutkan, "Demi jiwa dan penyempurnaan [ciptaan]Nya, maka Dia telah mengilhamkan [jalan] kejahatan dan ketakwaannya" (QS. al-Syams [91]:8).

Dalam drama kosmis Adam dan Hawa, posisi manusia berada di tengah antara malaikat sebagai makhluk saleh dan setan sebagai ruh jahat. Pada prinsipnya manusia dengan fitrahnya, adalah makhluk baik, karena telah didesign oleh Allah sesuai dengan fitrah-Nya yang tidak mengalami perubahan [QS. al-Rum (30):30]. Hanya saja kebaikan itu bisa berubah arah kepada keburukan, ketika ilham keburukan itu muncul dalam dirinya. Namun demikian, nurani manusia yang terdalam senantiasa konsisten menuju kebaikan. Ketika manusia telah bergelimang dengan dosa, nuraninya yang terdalam menjerit karena himpitan dosa itu. Dalam dirinya senantiasa ada panggilan untuk kembali kepada kebaikan. Akan tetapi, suara nurani itu kadang-kadang bisa tertutupi oleh suara-suara lain yang hangar-bingar, sehingga tidak kedengaran. ${ }^{4}$

Salah satu suara nurani itu adalah kesadaran tentang kebutuhan terhadap orang lain sebagai bukti kuat bahwa manusia pada dasarnya merupakan satu kesatuan kemanusiaan. Jika ada perbedaan identitas etnis, budaya, ideologi, afiliasi politik dan agama atau kepercayaan hanya merupakan implikasi historis dari respons manusia terhadap dinamika sosial yang hidup dan berkembang di sekitarnya. Namun demikian, di bumi manapun, atau dalam masa kapanpun manusia itu hidup, tetap saja merupakan manusia yang memiliki kesamaan substantif dengan manusia lain yang harus dihargai hak-haknya, memiliki kelebihan di samping kekurangan, dan oleh karenanya selalu membutuhkan orang lain. Dalam perspektif inilah, setiap manusia harus bisa menyadari pentingnya membangun kesadaran kolektif antarsesama manusia. ${ }^{5}$

STAIN Parepare sebagai sebuah komunitas akademik yang terdiri dari berbagai latar belakang pendidikan dan sosial, sangat membutuhkan kebersamaan dalam konteks yang lebih luas. Kesadaran kolektif harus dibangun dikampus ini agar visi misi STAIN dapat menjadi realitas, bukan menjadi impian belaka dan

${ }^{3}$ Lihat Yunasril Ali, 'Kekhalifahan dan Tanggung Jawab Moral: Menimba Inspirasi dari Mata Air Warisan Nurcholish Madjid', dalam Titik-Temu, Vol. 1, No. 1, Juli-Desember 2008, h. 76.

${ }^{4}$ Lihat Yunasril Ali, 'Kekhalifahan dan Tanggung Jawab Moral: Menimba Inspirasi dari Mata Air Warisan Nurcholish Madjid', dalam Titik-Temu, Vol. 1, No. 1, Juli-Desember 2008, h. 77.

${ }^{5}$ LihatNorman Said,, 'Memperkukuh Relasi Sosial Menuju Indonesia Baru', dalam Titik-Temu, Vol. 2, No. 1, Juli-Desember 2009, h. 51. 
hanya sekedar basa-basi. Keinginan untuk menjadi STAIN Parepare sebagai kampus yang bertaqwa untuk membawa berkah [BERUBAH] atau kampus yang dinanti, diminati dan diberkati (visi misi periode sebelumnya) hanya bisa terwujud jika dilandasi oleh kesadaran kolektif pada diri setiap insan kampus. Dalam konteks inilah, orasi ilmiah ini akan melihat bagaimana kesadaran kolektif atau kebersamaan itu dalam perspektif hadis.

\section{MENGUKUHKAN KEBERSAMAAN}

Sebagai makluk sosial di samping sebagai makhluk individu, manusia tidak bisa hidup sendiri. Kebutuhan terhadap orang lain mengharuskan seseorang untuk berusaha memposisikan diri secara tepat agar ia bisa diterima secara baik dalam suatu lingkungan sosial. Kemampuan memposisikan diri secara tepat dalam suatu lingkungan sosial yang terdiri atas berbagai kelompok sosial berlatar belakang intelegensi, etnis dan budaya yang berbeda-beda merupakan hal yang sangat signifikan dalam membangun satu tatanan kehidupan sosial yang bebas dari konflik yang dapat membawa kepada kekacauan sosial (social instability). ${ }^{6}$

Salah satu upaya yang efektif dalam memperkukuh kebersamaan adalah kesadaran untuk mengembangkan dialog ${ }^{7}$ secara intensif di kalangan anggota masyarakat, baik antara satu individu dan individu lain, maupun antara satu kelompok dan kelompok lain dalam suatu masyarakat. Dialog merupakan tawaran yang sangat baik dalam proses penciptaan sebuah komunitas yang bebas dari prasangka-prasangka sosial yang sering menjadi penyebab lahirnya sejumlah penyakit sosial, seperti kecemburuan sosial, diskriminasi sosial dan semacamnya. ${ }^{8}$ Dengan kata lain, jika sebuah komunitas dipenuhi oleh prasangkaprasangka sosial, maka hal itu menandakan bahwa dialog tidak menjadi ruh dan spirit bagi komunitas tersebut.

Aktivitas dialog yang melibatkan berbagai unsur masyarakat yang berlatar belakang sosial yang berbeda dapat dilakukan berdasarkan kenyataan sebagai berikut:

* Kesamaan hakikat kemanusiaan. Meskipun manusia yang satu berbeda dengan manusia lain, namun pada hakikatnya memiliki kesadaran kemanusiaan yang sama. Kesamaan ini berdasar atas kenyataan bahwa manusia berasal dari satu sumber yang sama. Kesamaan asal-usul inilah yang mempertalikan manusia

${ }^{6}$ Norman Said, 'Memperkukuh Relasi Sosial Menuju Indonesia Baru', dalam Titik-Temu, Vol. 2, No. 1, Juli-Desember 2009, h. 59.

${ }^{7}$ Menurut M. Quraish Shihab, jika merujuk kepada Alquan ditemukan sekian banyak bentuk dialog yang diperkenalkannya, antara lain; 1] Dialog pembuktian; 2] Dialog kecaman dan ancaman; 3] Dialog sindiran; 4] Tanya jawab. Lihat M. Quraish Shihab, Menabur Pesan Ilahi: Al-Qur'an dan Dinamika Kehidupan Masyarakat (Cet. I; Jakarta: Lentera Hati, 2006), h. 343.

${ }^{8}$ Norman Said, 'Memperkukuh Relasi Sosial Menuju Indonesia Baru', dalam Titik-Temu, Vol. 2, No. 1, Juli-Desember 2009, h. 59 
yang satu dengan manusia lain dalam semangat persaudaraan. ${ }^{9}$ Nabi saw. bersabda:

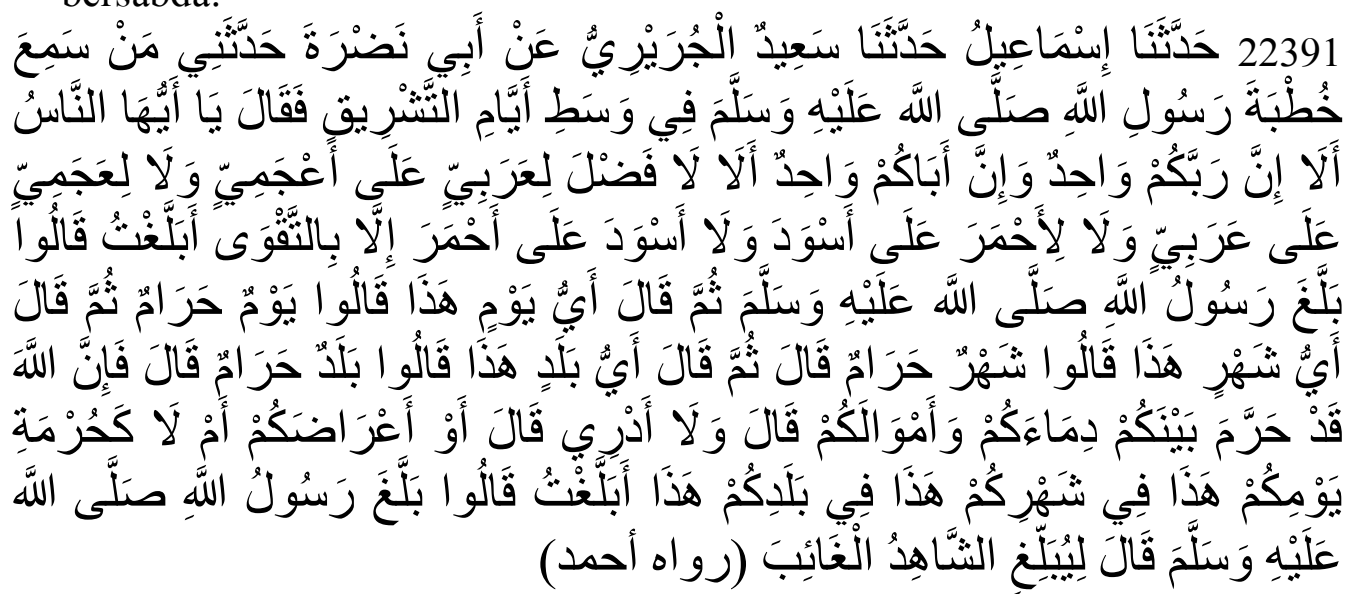

Ketergantungan antarsesama manusia. Setiap individu memiliki kelebihan dan kekurangan sekaligus yang menjadikan manusia selalu dalam keadaan siap untuk memberi dan siap untuk menerima. ${ }^{10}$

- Kesamaan kepentingan. ${ }^{11}$ Sebagai civitas akademika yang sama dengan visi dan misi mengembangkan kampus yang lebih baik, maka semua harus bekerja untuk mewujudkan visi misi tersebut.

Rasulullah saw. sebagai pemimpin dalam berbagai aspek, yang perkataan, perbuatan dan ketetapannya menjadi hadis telah mengaplikasikan model dialog. Bahkan banyak hadis-hadis Nabi yang lahir dari dialog antara Nabi dan sahabatsahabatnya atau para anggota masyarakat, sehingga matan hadis tersebut berbentuk percakapan (dialog). Misalnya hadis tentang amalan yang paling utama:

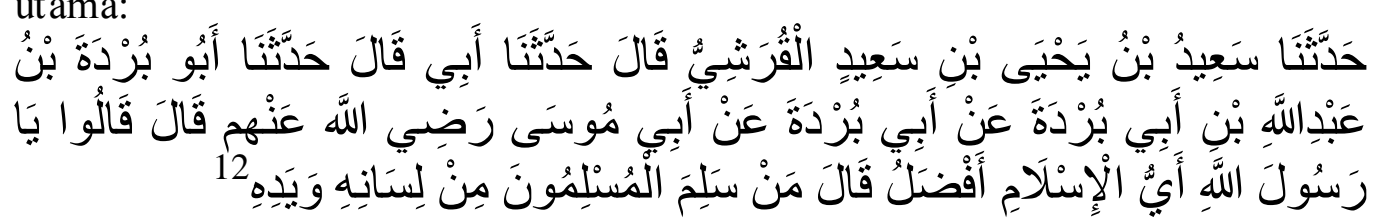

${ }^{9}$ Norman Said, 'Memperkukuh Relasi Sosial Menuju Indonesia Baru', dalam Titik-Temu, Vol. 2, No. 1, Juli-Desember 2009, h. 60

${ }^{10}$ Norman Said, 'Memperkukuh Relasi Sosial Menuju Indonesia Baru', dalam Titik-Temu, Vol. 2, No. 1, Juli-Desember 2009, h. 60.

${ }^{11}$ Norman Said, 'Memperkukuh Relasi Sosial Menuju Indonesia Baru', dalam Titik-Temu, Vol. 2, No. 1, Juli-Desember 2009, h. 60.

${ }^{12}$ Lihat al-Imām Abi 'Abdillah Muhammad bin Ismāīl bin Ibrāhim bin alMughirah bin Bardizbah al-Bukhāriy al-Ja'fiy, Sah̄̄h al-Bukhāri, jilid I, juz I (t.tp: Dār al-Fikr, 1994), h. 11 dan lain-lain; Abu Husain bin Muslim bin al-Hajjaj al-Qusyairiy, Shahih Muslim, jilid I (Beirut: Dar al-Fikr, t.th.), h. 65. Lihat Abi Isa Muhammad bin Isa bin Saurah, al-Jāmi' al-Sahīh wa huwa Sunan al-Turmudzi, di-tahqiq, di-takhrij dan dita'liq oleh Muhammad Fuad Abd. Al-Baqi, juz IV, (Beirut: Dār al-Kutub al-Ilmiyyah, t.th), h. 128-129. Lihat pula Abu Abdillah Ahmad bin Hanbal, Musnad Ahmad bin Hanbal, juz III, disertai catatan pingggir (hamisy) dari Ali bin Hisam al-Din al-Muqti, Muntakhab Kanzil Ummah fi Sunanil Aqwam wa af'al (Beirut: al-Maktabah al-Islami, 1398 H/ 1978 M), h. 163, 187 dan lain-lain; Abu Muhammad Abdillah bin Abd. al- 
“Mereka [para sahabat] Nabi bertanya: 'Ya Rasulullah, amalan Islam yang manakah yang lebih utama?'. Beliau menjawab: '[Yaitu] orang-orang yang memberikan keselamatan kepada muslim yang lain dari mulut dan tangannya".

Sebagai umat Rasulullah saw. yang kehidupannya menjadi uswah bagi kita semua, seharusnya dialog yang sifatnya secara kolektif harus menjadi bagian dari kehidupan kita. Ketakutan untuk berdialog secara kolektif dengan mengajak seluruh anggota komunitas, menunjukkan bahwa kita belum menjadikan Rasulullah saw. sebagai cerminan kehidupan kita.

\section{KONSEP KEBERSAMAAN DALAM PERSPEKTIF HADIS}

Langkah awal untuk menemukan hadis-hadis yang berkaitan dengan kebersamaan adalah kegiatan takhrij al-hadis. ${ }^{13}$ Term kebersamaan disepadankan dengan term al-jama'ah, sehingga dengan term tersebut kegiatan takhrij al-hadis dilakukan. Dengan menggunakan CD-Room Hadis, ditemukan bahwa kata aljama'ah disebutkan sebanyak 171 kali dalam sembilan kitab hadis. Makna aljama'ah dalam hadis dari 171 kali penyebutannya, dapat dikategorisasikan untuk sementara sebagai kajian awal-dalam empat hal, yakni kebersamaan dalam ibadah, kebersamaan merupakan sumber rahmat, kebersamaan merupakan sumber berkah dan kebersamaan melahirkan 'tangan' [kekuasaan dan pertolongan] Allah. Keempat kategori di atas akan menjadi lokus pembahasan berikutnya.

Rahman al-Darimiy, Sunan al-Darimiy, juz II (t.tp.: Dar al-Ihya' al-Sunnah alNabawiyah, t.th.), h. 299.

${ }^{13}$ Secara etimologis, kata takhrij (تخر يج) berarti berkumpulnya dua perkara yang berlawanan pada sesuatu yang satu. Kata takhrij sering dimutlakkan pada beberapa macam pengertian yang populer ialah 1] al-Istimbath (hal mengeluarkan); 2] al-Tadrib (hal melatih atau hal pembiasaan); dan 3] al-Tawjih (hal memperhadapkan). Lihat Mahmud al-Tahhān, Ushūl al-Takhrij wa Dirāsah al-Asānid, (Halb: Mathba'ah alArabiyyah, 1978), h. 9. dalam terminologi muhaddisin, takhrij al-hadis mempunyai beberapa arti; 1] mengemukakan hadis dengan menyebutkan periwayatnya dalam sanad yang telah menyampaikan hadis itu dengan sighat tahammul-nya; 2] Ulama hadis mengemukakan berbagai hadis yang telah dikemukakan dalam kitab-kitab hadis, yang susunannya berdasarkan riwayat hadisnya sendiri atau orang lain, dengan menerangkan siapa periwayatnya dari para penyusun kitab atau karya tulis yang dijadikan sumber pengambilan. Dalam kaitannya dengan metodologi penelitian hadis, maka yang dimaksud dengan takhrij al-Hadis adalah penelusuran atau pencarian hadis pada berbagai kitab sebagai sumber asli dari hadis yang bersaangkutan yang di dalam sumber itu dikemukakan secara lengkap sanad dan matan hadis yang bersangkutan. Lihat M. Syuhudi Ismail, Metodologi Penelitian Hadis Nabi (Cet. I; Jakarta: Bulan Bintang, 1992) h. 43

Aspek-aspek pokok perlunya kegiatan takhrīj adalah, 1] untuk mengetahui asal usul riwayat hadis yang akan diteliti; 2] untuk mengetahui seluruh riwayat hadis yang akan diteliti; 3] untuk mengetahui ada tidaknya syahid atau muttabi pada sanad yang diteliti. Lihat M. Syuhudi Ismail, Metodologi Penelitian Hadis Nabi, h. 41-42. 


\section{INDAHNYA KEBERSAMAAN \\ [Sebuah Ikhtiar dalam Membangun Kampus Bertaqwa Untuk Membawa Berkah (BERUBAH) dalam Perspektif Hadis]}

A. Kebersamaan dalam Ibadah $^{14}$

Dalam Islam, ibadah yang memiliki nilai tinggi dan utama adalah ibadah dilakukan secara bersama-sama. Ibadah salat misalnya, terdapat nilai yang berbeda antara salat sendirian dan salat berjamaah. Hal ini ditegaskan oleh Nabi saw dalam hadisnya yang terdapat pada kitab Sunan al-Nasāiy, ${ }^{15}$ kitab alImāmah, pada bab 42 ( bāb farḍu al-jamā'ah), matan hadis 833-835 yang berbunyi sebagai berikut:

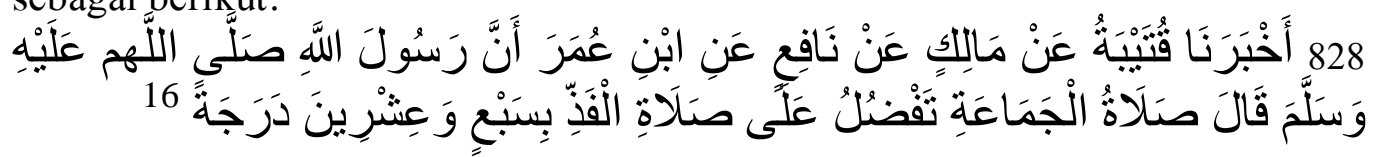

Artinya:

Imam al-Nasāiy berkata; Qutaybah memberitakan kepada kami, berkata; dari Mālik, berkata; dari Nāfi', berkata; dari Ibn 'Umar, berkata; Rasulullah saw bersabda: Shalat jamaah lebih afdhal dari shalat sendiri, yaitu 27 derajat.

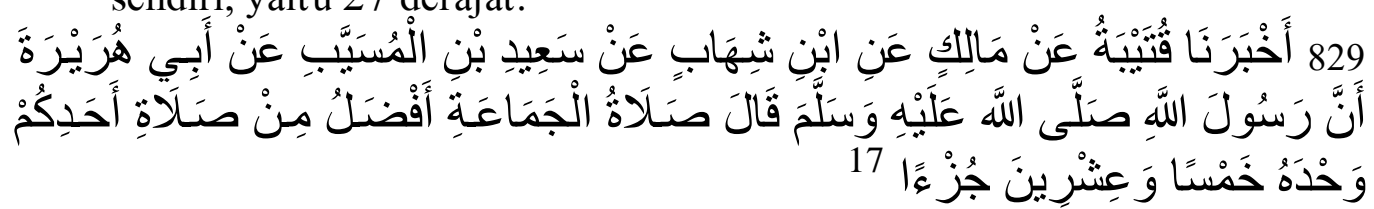

Artinya:

Imām al-Nasāiy berkata; Qutaybah memberitakan kepada kami, berkata; dari Malik, berkata; dari Ibn Syihāb, berkata; dari Sa'id bin Musayyab, berkata; dari Abu Huraerah, berkata; Rasulullah saw. bersabda: Shalat jamaah lebih afdhal dari shalat sendirian, yakni 25 pahala.

\footnotetext{
${ }^{14}$ Kata "ibadah" berasal dari bahasa Arab yang berakar kata ' $a-b$ - $d$, memiliki dua arti dasar yaitu kelembutan (layyin atau zall) dan kekasaran (syiddah atau galaz). Makna kelembutan dapat dipahami ketika ibadah diartikan sebagai hamba sahaya (mamluk). Term 'abada - ya'budu - 'ibadah digunakan khusus untuk Allah SWT, sedang ta'abbada - yata'abbadu - ta'abbudan digunakan untuk makna khadama (pelayan untuk raja). Sementara term 'abid (yang beribadah) hanya dilakukan untuk orang muslim dan 'abd atau 'abdah khusus untuk orang musyrik. Kemudian makna kekerasan dapat dipahami ketika kata 'ibadah diartikan sebagai kekuatan (al-quwah) dan mengalahkan (al-galabah). Lihat Abi al-Husain Ahmad ibn Faris ibn Zakaria, Mu'jam al-Maqayis fi al-Lugah, juz II (Cet.I; Beirut: Dar al-Fikr, 1994), h.128-129. Kata tersebut, menurut M. Quraish Shihab, dapat menggambarkan kekokohan ketika 'Abd diartikan "anak panah yang pendek dan lebar" (makna ini menggambarkan kekokohan). M. Quraish Shihab, Tafsir al-Qur'an alKarim Tafsir atas Surat-Surat Pendek Berdasarkan Urutan Turunnya Wahyu (Cet.I; Bandung: Pustaka Hidayah, 1997), h. 32.

${ }^{15}$ Selain ditakhrij oleh Imām al-Nasāiy, hadis tentang shalat jamaah juga ditakhrij oleh; (1) Imām Muslim dalam kitabnya Șậ̣h Muslim pada kitab Mawāqib, bab 245-246; (2) Imām Mālik dalam kitabnya al-Muwațta, pada kitab Jam'ah bab ke 20; dan (3) Imām Ahmad bin Hanbal dalam kitabnya Musnad Ahmad bin Hanbal, juz II; hal. 375, 486 dan 529.

${ }^{16}$ al-Nasāiy, Sunan al-Nasa'iy., juz II, h. 112

${ }^{17}$ al-Nasāiy, Sunan al-Nasa'iy., juz II, h. 112
} 


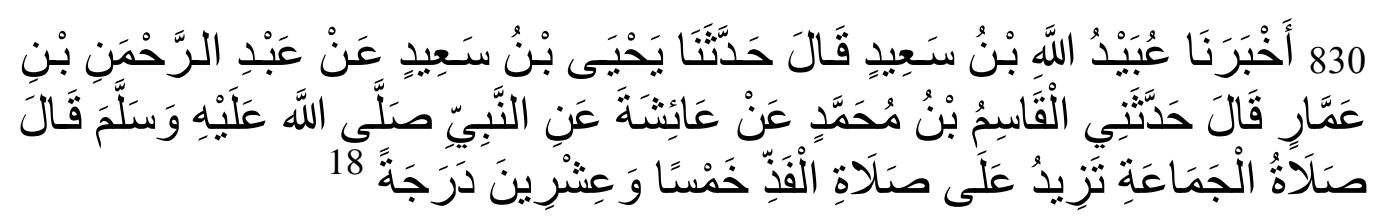

Artinya:

Imām al-Nasāiy berkata; 'Ubaydullah memberitakan kepada kami, berkata; Yahya bin Sa'id memberitakan kepada kami, berkata; dari Abd. al-Rahmān bin 'Umarah, berkata; al-Qāsim bin Muhammad, berkata; dari 'Aisyah, berkata; Nabi saw bersabda: Shalat jamaah mempunyai nilai tambah dari pada shalat sendirian, yaitu 25 derajat.

Berdasarkan berbagai informasi dari Alquran dan hadis, dapatlah disebutkan bahwa shalat adalah kewajiban peribadatan (formal) yang paling besar dan paling penting dalam sistem keagamaan Islam. ${ }^{19}$ Alquran banyak memberikan informasi tentang perintah agar kita menegakkan shalat (iqämat alsalah), yaitu menjalankannya dengan penuh kesungguhan, dan menggambarkan bahwa kebahagiaan yang pertama-tama dirasakan bagi orang-orang beriman adalah shalatanya yang dikerjakan dengan penuh ke-khusyu'an. ${ }^{20}$ Sebuah hadis Nabi saw juga menegaskan "yang pertama kali akan diperhitungkan tentang seorang hamba pada hari kiamat ialah shalat, jika baik, maka baik pulalah seluruh amalnya, dan jika rusak maka rusak pulalah seluruh amalnya." 21

Salat adalah ibadah yang mengajarkan untuk mengembangkan hidup kebersamaan. Bacaan wajib dalam salat yakni surah al-Fatihah ayat kelima 'Iyyāka na'budu wa Iyyāka nasta'īn' merupakan indikator yang sangat kuat bahwa orang-orang yang telah mendirikan salat harus membangun hidupnya dalam konsep kebersamaan. Redaksi ayat tersebut yang dalam bentuk jamak tidak boleh diubah dan wajib dibaca, meskipun salat ketika itu dilakukan sendirian.

Menurut M. Quraish Shihab, kekamian atau kebersamaan yang dikandung oleh ayat ini mengandung beberapa tujuan, yakni; Pertama, untuk menggambarkan bahwa ciri khas ajaran Islam adalah kebersamaan. Setiap muslim harus memiliki kesadaran merasa bersama dengan orang lain atau kesadaran sosial. Keakuan seseorang harus lebur secara konseptual bersama "aku" lainnya, sehingga kehidupannya seperti yang dilukiskan oleh Nabi saw. "bagaikan satu jasad yang merasakan keluhan bila salah satu organ merasakan

\footnotetext{
${ }^{18}$ al-Nasāiy, Sunan al-Nasa'iy., juz II, h. 112

${ }^{19}$ Lihat Norcholish Madjid, Shalat, dalam Budhy Munawar Rachman (Editor), Kontektualisasi Doktrin Islam Dalam Sejarah (Cet.II; Jakarta: Paramadina, 1995), h. 398

${ }^{20}$ Lihat QS. al-Mu'minūn (25):1-2 yang berbunyi sebagai berikut:

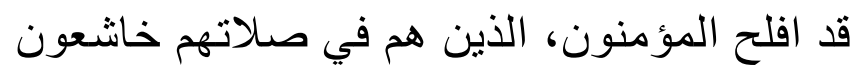

"Sungguh beruntung orang-orang yang beriman, yaitu orang-orang yang dalam shalatnya khusyu".

${ }^{21}$ Lihat Abū 'Abd. Allāh Muhammad Ibn Yazìd al-Qazwayniy Ibn Mājah, Sunan Ibn Mājah, jilid (Bayrūt: 'Isā al-Bābiy al-Ḥalabiy, t.th.), h. 450-451
} 
penderitaan". Kesadaran akan kebersamaan tidak hanya terbatas antar-sesama muslim atau sebangsa, tetapi mencakup seluruh manusia yang dibangun atas dasar prinsip bahwa seluruh manusia adalah satu kesatuan. Kedua, berkaitan dengan bentuk ibadah yang seharusnya dilakukan oleh setiap muslim, hendaknya dilakukan secara bersama, jangan sendiri-sendiri. Apabila dilakukan sendiri, maka kekurangan yang ada langsung disoroti dan pertanggungjawabannya bersifat individual. Namun jika dilakukan secara bersama, maka orang lain yang bersama itu dapat menutupi kekurangan ibadah kita. Dengan bersama atau berjamaah, kita bermohon kiranya kekeliruan kita dimaafkan karena adanya halhal yang sempurna yang dilakukan oleh mereka yang bersama kita. ${ }^{22}$

Salat adalah ibadah yang menggambarkan miniatur kehidupan manusia dalam berbagai aspeknya. Dengan salat berjamaah, Islam mendidik umatnya tentang urgensi bekerja dalam satu team secara bersama. Dalam aspek politik, ketika mendirikan salat secara berjamaah, berdiri dan menghadapkan wajah ke arah kiblat serta merapatkan saf, hal ini menunjukkan pentingnya bersatu padu, kerja sama dan disiplin dalam suatu komunitas. Selain itu, salat berjamaah juga mengingatkan umat tentang konsep persamaan di dalam Islam. Dalam aspek sosial, mereka yang salat berjamaah akan berdiri berdekatan antara satu dan lain, masing-masing menghadapkan wajah ke arah kiblat yang sama, serta menyembah Tuhan yang satu, tanpa memandang apakah dia seorang pimpinan, dosen atau mahasiswa. Demikian juga suasana yang harus dibangun dalam satu komunitas akademik. Perasaan ego, berbangga diri akan status dan keturunan harus dihapuskan jika satu lembaga ingin berhasil dalam mewujudkan visi misinya. ${ }^{23}$

Jika terjadi kesalahan ketika sedang salat, imam boleh ditegur. Jika kesalahan imam melibatkan rukun salat, makmun dilarang mengikuti imam, dan ketika itu dia hendaklah berniat mufarraqah atau berpisah dari imam. Demikianlah pula dalam satu tim. Ketua harus bertanggung jawab terhadap kepemimpinannya dan dia tidak boleh bertindak secara sembrono. Jika penyalahgunaan kekuasaan terjadi, atau ketua melanggar prinsip dan kebijakan, dia harus ditegur dan diperbaiki. ${ }^{24}$ Rasulullah saw. bersabda:

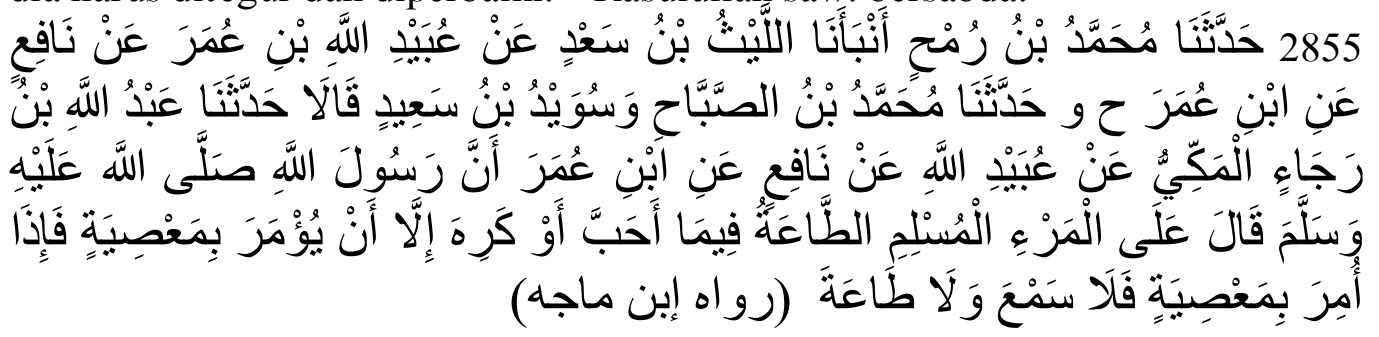

"Setiap Muslim dituntut agar mendengar dan menaati pemimpin di dalam hal yang mereka suka atau benci, kecuali jika disuruh melakukan maksiat. Ketika itu, tidak ada lagi tuntunan untuk mendengar dan taat"

${ }^{22}$ M. Quraish Shihab, Tafsir Al-Qur'an Al-Karim....., h. 35-36.

${ }^{23}$ Danial Zainal Abidin, Al-Qur'an For Life Excellence: Tips-Tips Cemerlang Dari Al-Qur'an (Cet. I; Bandung: Mizan, 2008), h. 220.

${ }^{24}$ Danial Zainal Abidin, Al-Qur'an For Life Excellence: Tips-Tips Cemerlang Dari Al-Qur'an, h. 220-221. 
Dalam hal pemimpin, Prof. Quraish Shihab menulis sebagai "Pesan Untuk Para Pemimpin", "Angkatlah mereka yang memiliki kecerdasan [intelektual, moral dan spiritual], pengalaman, pengetahuan menyangkut tugasnya, serta perhatian kepada masyarakat, dan perbanyaklah musyawarah, dengan mendorong setiap orang menyampaikan pedapatnya. Jangan memberi kesan, apalagi bertindak yang mengantar ke arah tersumbatnya suara. Tetapi, jangan bermusyawarah dengan penakut, karena dia mempersempit jalan keluar, jangan juga dengan yang kikir, karena dia menghambat Anda ke tujuan. Juga jangan dengan yang ambisius, karena dia dapat memperindah buat Anda sesuatu yang buruk". Selanjutnya jangan sekali-kali Anda terperdaya dengan orang-orang yang meraih kenikmatan melalui kekuasaan yang Anda miliki dan yang mengakibatkan Anda kelak menderita kesengsaraan. Mereka itu menikmati dunia mereka atas biaya hilangnya kenikmatan akhirat Anda. Jangan juga mata Anda tertuju sepenuhnya kepada kekuasaan yang Anda miliki dewasa ini, tetapi arahkanlah pandangan ke hari esok, ketika Anda terbelenggu kematian, berdiri menghadap Allah".

Salat merupakan institusi iman ketika sebuah keyakinan dan orientasi keilahian diterjemahkan dan dikaitkan dengan orientasi praksis untuk menciptakan salam di antara sesama manusia. Dengan kata lain, rentangan spektrum Ilahi di satu sisi dan spektrum kemanusiaan di sisi lain secara metafisis tidaklah tepat jika diposisikan dalam perspektif ruang sebagaimana ruang yang kita pahami dalam hidup keseharian. Tetapi keduanya menyatu dalam sebuah kesadaran, sehingga bagi seorang muslim perilaku kemanusiannya hendaknya memuat kualitas Ilahi, dan kehangatan dalam ber-Tuhan hendaknya terefleksikan dalam perilaku kemanusiannya.

Keadaan tersebut kita bisa menamakannya dengan "kesatuan gerak", yakni gerakan keilahian dan sekaligus juga gerakan kemanusiaan. Perilaku yang bersifat Ilahi berakar pada kesadaran batin, seperti firman Allah dalam QS. alRa'd [13]:11 bahwa pertolongan Allah untuk mengubah nasib suatu kaum itu akan tiba ketika mereka terlebih dahulu berhasil mengubah situasi kejiwaan batin mereka. Artinya, tanpa adanya kesadaran, kesanggupan dan sikap batin untuk meyakini dan meraih Realitas Tertinggi, yang gaib dan berada di luar jangkauan indera dan rasio, maka betapa pendeknya dan betapa kecilnya apa yang bisa diberikan dunia materi ini terhadap tuntutan manusia yang jangkauan hidupnya menerobos dinding-dinding materi.

Penyakit manusia modern hari ini, adalah ketidakmampuan manusia untuk membedakan mana malaikat dan mana iblis. Kadangkala orang yang mengkritik kita, memberikan masukan kepada kita, hanya karena kritikan dan masukannya dianggap bertentangan dengan kepentingan kita, kita tidak mengubrisnya, padahal dia malaikat; sebaliknya orang yang senantiasa mendukung kita, senantiasa pujian yang dia berikan atas pekerjaan kita; kita terima begitu saja, padahal boleh jadi orang itulah yang akan mencelakakan kita dan menjatuhkan wibawa dan kehormatan kita.

B. Kebersamaan sumber rahmat 


\section{INDAHNYA KEBERSAMAAN \\ [Sebuah Ikhtiar dalam Membangun Kampus Bertaqwa Untuk Membawa Berkah (BERUBAH) dalam Perspektif Hadis]}

Kebersamaan merupakan sumber rahmat dari Allah swt., karena rahmatNya hanya terdapat pada mereka yang menyebarkan rahmat di muka bumi. Mereka dapat membangun hidup dengan kebersamaan jika tidak ada kebencian dan kecemburuan dalam dada mereka, yang ada hanyalah kasih sayang di antara mereka. Nabi saw. bersabda dalam sebuah hadisnya:

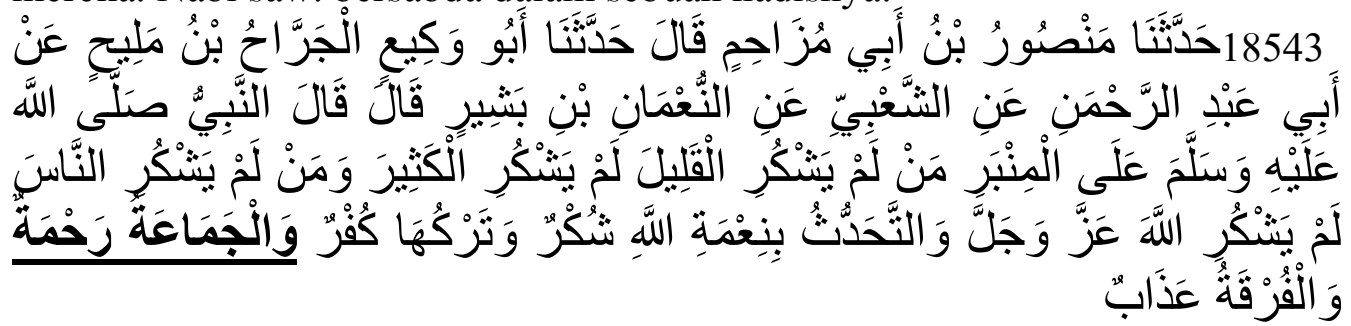

Hadis di atas disampaikan oleh Nabi saw. melalui media khutbah atau ceramah di atas mimbar yang menjelaskan tentang syukur bahwa kesyukuran yang sifatnya besar harus dimulai dari kesyukuran yang sifatnya kecil; kesyukuran kepada Allah swt. harus diawali dari kesyukuran kepada sesama manusia. Inilah awal dari kebersamaan yang akan melahirkan rahmat dan perpecahan yang menimbulkan azab.

Kesyukuran kepada sesama manusia sebagai landasan kesyukuran kepada Allah merupakan ajaran agama yang mengajarkan bahwa masing-masing jiwa manusia mempunyai harkat dan martabat yang senilai dengan manusia sejagad. Masing-masing pribadi manusia mempunyai nilai kemanusiaan universal. Maka kejahatan kepada seorang pribadi adalah sama dengan kejahatan kepada manusia sejagad, dan kebaikan kepada seorang pribadi adalah sama dengan kebaikan kepada manusia sejagad. Inilah dasar yang amat tegas dan tandas bagi pandangan kewajiban manusia untuk menghormati sesamanya dengan hak-hak asasinya yang sah.

Islam adalah agama yang mengutamakan hubungan baik dengan Allah dan hubungan baik dengan sesama manusia. Hubungan baik dengan Allah tercapai melalui takwa. Hubungan baik dengan sesama manusia tercapai melalui akhlak. Akhlak mulia berkaitan erat dengan iman. Nabi pernah ditanya, "Ya Rasulullah, mukmin manakah yang lebih utama imannya?" Nabi menjawab, "Yang terbaik akhlaknya".

Jika kita telaah firman Allah berikut tentang hak-hak pribadi dan kewajiban sosial akan tampak pada kita hubungan dengan prinsip-prinsip kelapangan dada, keterbukaan, penuh pengertian dan kerendahan hati yang dituntut pada setiap orang. Artinya, hak-hak pribadi dan kewajiban sosial tidak akan terwujud dengan baik, jika tidak disertai kelapangan dada, kerendahan hati, keterbukaan dan toleransi kepada orang lain..

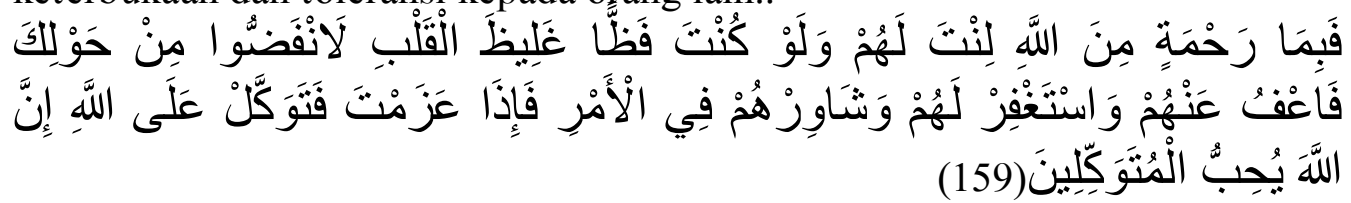

"Adalah karena rahmat dari Allah, maka Engkau (Muhammad) berlaku lemah lembut kepada mereka (para sahabatnya). Sekiranya Engkau kejam dan berhati kasar, tentulah mereka menjauh dari lingkunganmu. Maka maafkanlah 
mereka, dan mohonkan ampun untuk mereka, serta bermusyawaralah dengan mereka dalam (segala) urusan. Jika kemudian Engkau telah ambil keputusan, maka bertawakallah kepada Allah. Sesungguhnya Allah cinta kepada mereka yang bertawakal".

Sangat menarik, bahwa dalam ayat di atas, semuanya dimulai dengan adanya rahmat atau kasih Allah kepada Nabi saw. suatu petunjuk adanya hubungan positif dan keseimbangan antara hak-hak pribadi dan kewajiban sosial. Rahmat Allah itu berkaitan langsung dengan keseimbangan hak-hak pribadi dan kewajiban sosial. Oleh karena itu, Nabi diperintahkan Tuhan untuk selalu mengajak mereka bermusyawarah dalam membuat keputusan-keputusan bersama, dan perintah Tuhan itu beliau laksanakan dengan teguh dan setia.

Fakhruddin al-Razi, penulis Tafsir al-Kabir mengatakan bahwa nilai positif dari sikap Nabi dan perintah musyawarah adalah; 1] musyawarah merupakan bentuk penghargaan terhadap orang lain sehingga menghilangkan anggapan paternalistik bahwa rakyat atau orang lain itu rendah dan bodoh dan pemimpin itu paling tahu; 2] meskipun Nabi adalah pribadi yang sempurna dan cerdas, namun sebagai manusia ia memiliki kemampuan yang terbatas; 3] menghilangkan buruk sangka; 4] mengeliminasi beban psikologis kesalahan. Maksudnya, kesalahan mayoritas dari sebuah hasil musyawarah menjadi tanggungjawab bersama dan lebih bisa ditoleransi dari pada kesalahan keputusan individu.

John C. Maxwell, pengarang buku Developing the Leaders Arounds You mengatakan, "Kemahiran interpersonal berkaitan erat dengan sifat tidak mementingkan diri sendiri, mampu memahami kehendak manusia dan senantiasa mementingkan pergaulan yang baik sesama manusia. Sikap kita terhadap orang lain menentukan sikap orang lain terhadap kita. Pemimpin yang cemerlang pentingnya hal ini".

C. Kebersamaan merupakan sumber berkah

Dalam Kamus Besar Bahasa Indonesia, berkah adalah karunia Tuhan yang mendatangkan kebaikan bagi kehidupan umat manusia. ${ }^{25}$ Kebersamaan akan melahirkan kebaikan-kebaikan sebagai implikasi dari saling menghormati, saling membantu, saling merasakan dan saling menghargai di antara anggota masyarakat. Prinsip dan karakter seperti ini harus dimiliki oleh setiap orang agar tercipta sebuah kerukunan dalam berinteraksi secara horisontal. Nabi saw. bersabda:

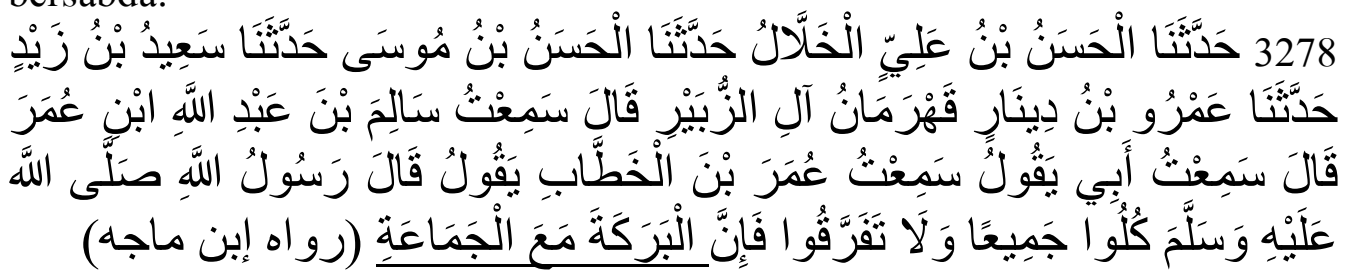

${ }^{25}$ Departemen Pendidikan dan Kebudayaan, Kamus Besar Bahasa Indonesia, Edisi ke II (Jakarta : Balai Pustaka, 1966), h. 124. 


\section{INDAHNYA KEBERSAMAAN \\ [Sebuah Ikhtiar dalam Membangun Kampus Bertaqwa Untuk Membawa Berkah (BERUBAH) dalam Perspektif Hadis]}

Pesan utama dari hadis di atas adalah perintah Nabi saw. untuk makan secara bersama-sama dan tidak bercerai berai sehingga mendapatkan berkah dari Tuhan. Makna dari keberkahan dalam soal makanan adalah mendatangkan kekenyangan. ${ }^{26}$ Apabila makan secara bersama-sama, maka tidak ada orang yang merasa kelaparan. Nabi saw. pernah mengungkapkan bahwa tidak sempurna iman seseorang jika ia tidur kekenyangan, sedangkan tetangganya kelaparan.

D. Kebersamaan melahirkan pertolongan Allah

Kategori keempat ini didasarkan pada hadis Nabi saw. yang berbunyi:

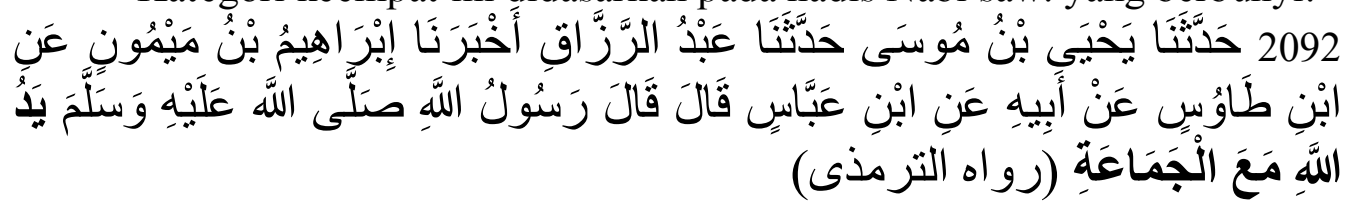

Kebersamaan dapat dibangun jika masing-masing individu memiliki sikap untuk saling memberi pertolongan. Pertolongan kepada sesama manusia akan melahirkan pertolongan dari Allah swt. Dalam sebuah hadis yang diriwayatkan oleh Bukhari dan Muslim dari sahabat Abu Hurairah, Nabi bersabda, 'Allah akan selalu memberi pertolongan kepada seseorang selama ia memberi pertolongan kepada saudaranya [sesamanya].

Ungkapan Nabi di atas menunjukkan bahwa pertolongan Allah akan datang melalui kerjasama antara manusia. Sebagai makhluk sosial, seseorang harus sadar bahwa ia tergantung kepada pihak lain, di mana kebutuhannya tidak dapat terpenuhi melalui usahanya, usaha kelompoknya bahkan usaha bangsanya sendiri. Hidup hanya mungkin dan nyaman apabila dibagi dengan orang lain, sehingga masing-masing berperan serta dalam menyediakan kebutuhan bersama.

Kehidupan kemasyarakatan yang sehat adalah pada saat setiap anggotanya menghargai anggota yang lain betapapun terdapat perbedaan pendapat, ras, suku atau kepercayaan dan agama. Kesemua anggota masyarakat harus menghargai aturan, kode etik, batasan serta menawarkan cinta kasih kepada anggota masyarakat lainnya. Dengan demikian, setiap orang tidak menginginkan untuk orang lain apa yang tidak dinginkannya bagi dirinya. Kalau ini dapat diwujudkan, maka syarat pertama dari kehadiran bantuan Tuhan telah terpenuhi.

\section{PENUTUP}

Manusia sehat adalah manusia yang memiliki hubungan dengan manusia lain. Oleh karena itu, dalam Islam -yang kemudian dikembangkan oleh Ilmu Manajemen Modern-semua manusia, sekecil apapun peran, kedudukan dan

\footnotetext{
${ }^{26}$ Selain keberkahan dalam soal makanan, al-Thaba'thaba'iy merinci bentuk keberkahan pada semua segi kehidupan yakni; 1] keberkahan dalam berketurunan dengan lahirnya generasi-generasi yang kuat di segala bidang dan harta benda yang melimpah ruah; 2] keberkahan dalam hal waktu, seperti banyaknya waktu yang disediakan oleh Allah untuk berusaha memenuhi kebutuhan hidup dan mengembangkan ilmu pengetahuan. Lihat M. Quraish Shihab, Ensiklopedi Al-Qur'an: Kajian Kosa Kata dan Tafsirnya (Jakarta: PT. Intermasa, 1997), h. 56.
} 
fungsinya, semuanya penting dan strategis. Cleaning servis dan sekurity misalnya, yang mungkin oleh sementara orang dianggap tidak penting -yang ditunjukkan dengan miskinnya penghargaan terhadap mereka--, tetapi Islam menganggapnya adalah penting. Oleh karena itu, semua manusia harus dihargai sehingga Islam sangat melarang keras mengejek dan mengolok-ngolok.

Untuk membangun lembaga pendidikan yang berkualitas dengan pondasi ketaqwaan untuk mendapatkan berkah, maka kebersamaan harus menjadi sikap dan jati diri pada setiap insan akademik. Kampus harus menjadi rumah kasih sayang antara pimpinan, dosen dan mahasiswa. Kampus harus mendidik setiap penghuninya untuk memiliki sikap kelapangan dada, kerendahan hati, keterbukaan dan toleransi kepada orang lain. Kampus harus mendidik penghuninya untuk mendengar pendapat orang lain. Karena sekali seseorang merasa tidak perlu mendengar pendapat orang lain - yang berarti ia sengaja melepaskan diri dari ikatan sosial kampus berdasarkan hak dan kewajiban saling memberi isyarat tentang kebaikan dan kebenaran itu--, maka ia akan terjerembab ke dalam lembah kezaliman seorang tăghüt (tiran dan diktator). Dalam keadaan seperti itu, maka ia akan berkembang menjadi musuh masyarakat kampus, disebabkan dorongan pada dirinya yang bertindak sewenang-wenang karena merasa diri sendiri paling baik dan benar.

Beriman kepada Allah berarti memandang diri sendiri sama dengan orang lain, dengan potensi yang sama untuk benar dan untuk salah. Keimanan membuat orang menjadi rendah hati dan tawadhu, bersedia melakukan musyawarah atau dialog dengan sesamanya. Dia tulus untuk kemungkinan menerima kebenaran orang lain dan mengakui kesalahan diri sendiri. Dalam bahasa modern, seorang yang beriman tidak akan menjadi diktator, despot, tiran, totaliter dan sebangsanya, melainkan menjadi demokratis dan egaliter (berpaham kesamaan asasi semua orang).

Keimanan (tauhid) sebagai proses pembebasan diri (self liberation) akan menjadikan diri seseorang sebagai 'manusia yang terbuka', yang secara kritis selalu tanggap kepada masalah-masalah kebenaran dan kepalsuan yang ada di tengah-tengah masyarakat. Sikap tanggap itu, ia lakukan dengan keinsyafan sepenuhnya akan tanggungjawab atas segala pandangan dan tingkah laku serta kegiatan dalam hidup ini. Yang semuanya lahir dari rasa keadilan dan perbuatan positif kepada sesama manusia (al-Ihsan).

Implikasi pembebasan diri melalui tauhid akan melahirkan manusia dari yang sifatnya individual kepada yang lebih sosial. Menurut Nurcholish Madjid, prinsip tauhid dalam Alquran berkaitan erat dengan sikap menolak tagh $\bar{u}$ t (apaapa yang melewati batas), sehingga konsekuensi logis tauhid adalah pembebasan sosial yang bersifat egalitarianisme dan demokratis. Maka dari itu, tauhid menghendaki sistem kemasyarakatan yang demokratis berdasarkan syüra' (musyawarah) yang memungkinkan masing-masing anggota masyarakat saling memperingatkan tentang apa yang benar dan baik, dan tentang ketabahan dalam menghadapi perjalanan hidup, serta saling cinta kasih sesama manusia [QS. alAshr (103):3 dan QS. al-Balad (90):17]. 
Kedudukan manusia sebagai makhluk sosial meniscayakan adanya akhlak. Namun sebagai makhluk sosial, secara individu dia memiliki ego dan kepentingan yang dapat bertentangan dengan ego dan kepentingan orang lain. Olehnya itu, setiap individu dituntut untuk mengorbankan sedikit atau banyak dari kepentingan atau egonya itu agar dapat terjalin hubungan harmonis dan dapat pula terpenuhi kebutuhan-kebutuhannya untuk hidup bermasyarakat.

Pengorbanan melahirkan moral dan akhlak terpuji dan kesediaan berkorban merupakan manifestasi dari akhlak yang luhur. Semakin besar pengorbanan semakin luhur pula akhlak. Tanpa pengorbanan, akhlak tidak dapat tegak dan tanpa akhlak, masyarakat tidak akan dapat menjalankan fungsinya secara baik. Suatu masyarakat dinilai sakit dan akan punah, bila anggota masyarakat tidak memiliki kesediaan untuk berkorban. Karena pengorbanan terkait erat dengan akhlak yang luhur, maka sangat populer dalam literatur keagamaan dan moral kata-kata bersayap penyair kenamaan Mesir, Ahmad Syauqi, yang menyatakan:

$$
\text { إنما الأمم الأخلاق ما بقيت = فإن هُمُّو أذهبت أخلاقهم ذهبوا }
$$

“Kelanjutan eksistensi satu masyarakat ditentukan oleh tegaknya moral anggota masyarakat itu, dan kepunahannya terjadi pada saat keruntuhan moralnya".

Dengan demikian, tanpa kebersamaan dan kesediaan berkorban, tanpa akhlak dan budi luhur, kita tidak akan pernah mengubah STAIN menjadi lebih baik. 


\section{DAFTAR PUSTAKA}

Abidin, Danial Zainal, Al-Qur'an For Life Excellence: Tips-Tips Cemerlang Dari Al-Qur'an, Cet. I; Bandung: Mizan, 2008.

Ali, Yunasril, 'Kekhalifahan dan Tanggung Jawab Moral: Menimba Inspirasi dari Mata Air Warisan Nurcholish Madjid', dalam TitikTemu, Vol. 1, No. 1, Juli-Desember 2008.

al-Bukhāriy, al-Imām Abi 'Abdillah Muhammad bin Ismā̄l bin Ibrāhim bin al-Mughirah bin Bardizbah al- al-Ja'fiy, Sahīh al-Bukhāri, jilid I, juz I, t.tp: Dār al-Fikr, 1994.

al-Darimiy, Abu Muhammad Abdillah bin Abd. al-Rahman, Sunan alDarimiy, juz II, t.tp.: Dar al-Ihya' al-Sunnah al-Nabawiyah, t.th.

Departemen Pendidikan dan Kebudayaan, Kamus Besar Bahasa Indonesia, Edisi II, Jakarta : Balai Pustaka, 1966.

Ibn Faris, Abi al-Husain Ahmad ibn Zakaria, Mu'jam al-Maqayis fi alLugah, juz II, Cet.I; Beirut: Dar al-Fikr, 1994.

Ibn Hanbal, Abu Abdillah Ahmad, Musnad Ahmad bin Hanbal, juz III, disertai catatan pingggir (hamisy) dari Ali bin Hisam al-Din alMuqti, Muntakhab Kanzil Ummah fi Sunanil Aqwam wa af'al Beirut: al-Maktabah al-Islami, 1398 H/ 1978 M.

Ibn Mājah, Abū 'Abd. Allāh Muhammad Ibn Yazỉd al-Qazwayniy, Sunan Ibn Mājah, jilid, Bayrūt: 'Isā al-Bābiy al-Ḥalabiy, t.th.

Ibn Muslim, Abu Husain bin al-Hajjaj al-Qusyairiy, Shahih Muslim, jilid I, Beirut: Dar al-Fikr, t.th.

Ibn Saurah, Abi Isa Muhammad bin Isa, al-Jāmi' al-Sahīh wa huwa Sunan al-Turmudzi, di-tahqiq, di-takhrij dan di-ta'liq oleh Muhammad Fuad Abd. Al-Baqi, juz IV, Beirut: Dār al-Kutub al-Ilmiyyah, t.th.

Ismail, M. Syuhudi, Metodologi Penelitian Hadis Nabi, Cet. I; Jakarta: Bulan Bintang, 1992.

Madjid, Norcholish, Shalat, dalam Budhy Munawar Rachman (Editor), Kontektualisasi Doktrin Islam Dalam Sejarah, Cet.II; Jakarta: Paramadina, 1995.

Said, Norman, 'Memperkukuh Relasi Sosial Menuju Indonesia Baru', dalam Titik-Temu, Vol. 2, No. 1, Juli-Desember 2009.

Shihab, M. Quraish, Dia Dimana-mana: Tangan Tuhan Dibalik Setiap Fenomena, Cet. IV; Jakarta: Lentera Hati, 2006. 
, Ensiklopedi Al-Qur'an: Kajian Kosa Kata dan Tafsirnya, Jakarta: PT. Intermasa, 1997.

, Menabur Pesan Ilahi: Al-Qur'an dan Dinamika Kehidupan Masyarakat, Cet. I; Jakarta: Lentera Hati, 2006.

Tafsir Al-Qur'an Al-Karim: Tafsir atas Surah-Surah Pendek Berdasarkan Urutan Turunnya Wahyu, Cet. I; Bandung: Pustaka Hidayah, 1997.

al-Tahhān, Mahmud, Ushūl al-Takhrij wa Dirāsah al-Asānid, Halb: Mathba'ah al-Arabiyyah, 1978. 